\title{
NEWS
}

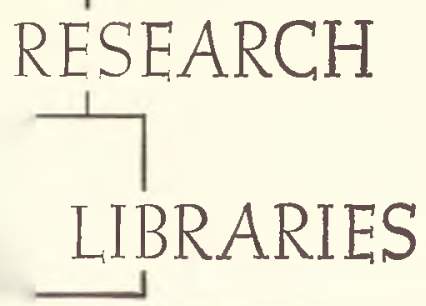

No. 3, March, 1967

ACRL News Issue (A) of College \& Research Libraries, Vol. 28, No. 2

\section{Library Statistics, 1965/66 Now Available}

In the September ACRL News issue, Robert L. Talmadge, chairman of the LAD Statistics Committee for College and University Libraries, related in some detail the necessity for LAD to undertake on an emergency basis 1965/66 survey of institutional data for academic libraries. Is was hoped, he stated, that the publication of these statistics could be accomplished by the end of January.

On March 15 copies of the 1965/66 survey were mailed to all academic institutions and universities who had placed advanced orders. The pricing of the publication is based only on cost of printing. The funds for the collection, analysis, and tabulation of data were provided by a small contract grant from the Bureau of Research, USOE, and from funds made available by the ALA Executive Board.

Library Statistics of Colleges and Universities, 1965-66: Institutional Data, (ALA, $\$ 3.50$ ), 240 p. (The 1963-64 survey was 162 pages in length), consists of three basic tables.

Table I is on "Selected Management Data on College and University Libraries, By State and Institution: Aggregate United States, 1965-66."

Table II is on "Operating Expenditures, Personnel and Beginning Salary. For College and University Libraries, By State and Institution: Aggregate United States, 1965-66."

Table III is on "Number of Full-time Library Staff Members and Lowest and Highest Salaries, By Types of Position: Aggregate United States, September 1, 1966."

The summary table is: "Summary of College and University Library Statistics for Academic Years 1959-66: Aggregate United States." This precedes the 1965/66 data.

Since the decision was taken in New York, to undertake this publication problems have been many. Thanks to the cooperation of Alexander M. Mood, assistant commissioner for educational statistics, USOE, and Joseph A. Murnin, director, Small Projects Program, Chicago Regional Office, Bureau of Research, USOE, the grant was approved in record time. Actual printing and mailing of the questionnaire before September 10 preceded the grant. This was absolutely necessary if we were to meet the deadline for publication.

Returns were slow in coming and required a number of follow-ups. The cooperation of state agencies in collection of the data was excellent. As a result, this survey contains 86 per cent return-the highest in the history of academic statistics for a single publication. A major crisis oc- 
curred in December when the data processing firm that had tentatively agreed to analyse and tabulate the data determined that it could not undertake this assignment. I turned to old reliable friends, Frank Schick and Theodore Samore, formerly of USOE, but now at the school of library and information science in the University of Wisconsin-Milwaukee. Could the University of Wisconsin-Milwaukee, through their library school and data processing center, undertake this task on short notice. A visit to the campus and a full day's activity resulted in a contract with the university. $\mathrm{Mr}$. Samore, under Frank Schick's supervision, edited the data and prepared it for the computer. The final printouts reached the LAD office on February 13.

This project is, I think, an excellent example of what can be done when the need is important-with strong determination, good cooperation and a concentrated effort from agencies USOE, LAD, University of Wisconsin-Milwaukee, the state agencies, and the academic institutions participating in this survey.-Alphonse T. Trezza, Executive Secretary, LAD.

\section{"ABOVE AND BEYOND"}

In the Winter/Spring 1966 issue of the Calibrarian newsletter, Robert Vosper, University Librarian, UCLA, and immediate past president of ALA, wrote the following at the editor's request.

"One of my predecessors is said to have remarked that the ALA presidency took ten years off his life span. I trust the results are not always quite so brutal, but it is true that the three year period, during which the ALA president is committed to heavy statutory responsibilities, does blot up a remarkable amount of time, energy, and even of personal finances, all of which must somehow be maneuvered while still (hopefully) staying on top of one's own job back home. More than once this past year I have been struck by the ironical fact that many ALA members actually assume that I am on official leave (with pay?) from UCLA, and thus left with nothing to do but travel to state meetings and White House Conferences, preparing a special and publishable speech for each such occasion of course, while working arm in arm with the Headquarters staff. I have even been asked whether I have moved to Chicago. I understand that the presidents of NEA and of the JC's live in such bliss (although not in Chicago I trust) but not ALA's president.

"I am also frequently asked: "But isn't the
University of California terribly proud of your position and thus prepared to cover you with additional staff and expense budgets?" Well, some universities might feel that way; but I would guess that, in light of the number of Nobel laureates and Academy members around the place, the University of California, while not blasé, can face one more such office, or the lack of it, with some equanimity. Therefore, as a matter of fact, I and the ALA in general owe a special debt to my secretary and to my associates at UCLA who necessarily absorb greater workloads while I get all the visibility and publicity.

"There is further irony in the expectations laid upon the president of ALA. At one end of the scale I, who have never invested a dime in anything and have shamefully never read an issue of the Wall Street Journal, am required to chair a meeting at which ALA's learned investment trustees forcefully discuss basic investment policy and practice for our $\$ 4,000,000$ portfolio with a battery of vicepresidents of the First National Bank of Chicago. At the other end of the scale I must try to live up to the expectations of people who say publicly, and with all evidence of sincerity, that I really cannot know how exciting it is actually to meet an ALA president! And in between I am expected to speak responsibly (I would say 'pontifically') before any group at any time on any library subject. I must say that all of this gives me pause: I worry about the fate of ALA under the circumstances, and I also worry about the erosion of my own character.

"However, I do not really want to sound bleak about all this. More importantly, I am increasingly convinced that all of us, if we have any sense of professional integrity, should support the ALA much more than we now do, to the point of personal sacrifice. In San Francisco at the CLA banquet I tried to say why this is increasingly the case, so I will not repeat the arguments here, only the plea. I have little respect for librarians who fail to join the ALA. I have less respect for chief librarians who fail to foster membership and participation. I have little patience with members who sit at home and complain that the ALA is not responsive to membership or that it does nothing for its members. In my book the ALA's primary responsibility is to serve the profession, and I believe that in general it does this well. It is hampered in this task only by those librarians who are not prepared to think and to act in professional terms. I am convinced that all members can and should be prepared to do more than just pay dues and wander through annual conferences. The ALA fully deserves active and devoted service from all librarians." 